\title{
Middle Jurassic - Early Cretaceous rifting of the Danish Central Graben
}

\author{
Jens J. Møller and Erik S. Rasmussen
}

During the Jurassic - Early Cretaceous, the Danish Central Graben developed as a N-S- to NNWSSE-trending graben bounded by the Ringkøbing-Fyn High towards the east and the Mid North Sea High towards the west. The graben consists of a system of half-grabens and evolved by faultcontrolled subsidence; three main rift pulses have been recognised. The first pulse ranged from the Callovian to the Early Oxfordian, the second pulse was initiated in the latest Late Kimmeridgian and lasted for most of the Early Volgian, and the third and final pulse occurred within the Ryazanian in the Early Cretaceous.

The first pulse was characterised by subsidence along N-S-trending faults. The most pronounced fault-controlled subsidence occurred in the east, especially along N-S-striking segments of the boundary fault to the Ringkøbing-Fyn High. During this period, minor salt movements occurred with the development of salt pillows. The activity along the N-S-trending faults ceased during the Oxfordian. During the second pulse, in Early Volgian times, subsidence was concentrated along new NNW-SSE-trending faults and the main depocentre shifted westward, being most marked within the Tail End Graben, the Arne-Elin Graben, and the Feda Graben. This tectonic event was accompanied by the accumulation of a relatively thick sediment load resulting in the development of salt diapirs, especially within the Salt Dome Province. The third tectonic pulse was essentially a reactivation of the NNW-SSE-trending structures and there is clear evidence of subsidence controlled by faulting and salt movements. Despite the overall extensional tectonic regime, local compressional tectonics resulted in thrusting. For instance, the Gert Ridge is interpreted to have formed by readjustment at the boundary fault between two subsiding blocks.

The structural framework during graben evolution controlled, to some degree, the distribution of reservoir sandstones. Reservoir sandstones associated with periods of rotational tilt include Middle Jurassic deposits referred to the Bryne and Lulu Formations, and Upper Jurassic sandstones referred informally to the 'Fife Sandstone Formation'. Sands deposited during tectonic relaxation are represented by the Heno Formation and Upper Jurassic turbidites interbedded in the Farsund Formation. Sea-level changes were probably most important during periods of tectonic relaxation, particularly with respect to the deposition of lowstand sandstones in basinal areas.

Keywords: North Sea, Danish Central Graben, Middle Jurassic - lowermost Cretaceous, 3D seismic data, structural evolution, reservoir sandstone distribution

Geological Survey of Denmark and Greenland, Geocenter Copenhagen, Øster Voldgade 10, DK-1350 Copenhagen K, Denmark. E-mail: jjm@geus.dk

The structural development of the Danish part of the Central Graben during the Jurassic has previously been described by Andersen et al. (1982), Gowers \& Sæbøe
(1985), Møller (1986), Cartwright (1987), and Korstgård et al. (1993). The structural evolution of the Norwegian Central Trough (Graben) has been presented by Gowers 
et al. (1993). These papers are based on interpretation of 2D multichannel seismic data acquired during the early 1980s. Despite the relatively high quality of these data, new information has come to light as a result of recentlyacquired 3D seismic data and information from wells drilled in the late 1980s and in the early part of this decade. The purpose of this paper is to present our interpretation of the evolution of the Danish Central Graben, on the basis of these new data. Furthermore, mapping of oil and gas fields demonstrates a close link between the structural framework and the location of reservoir rocks, in this case, sandstones. Therefore, the influence of the structural framework on the distribution of reservoir sandstones is discussed.

\section{Geological framework}

\section{Structural development}

The Danish Central Graben is a major east-dipping halfgraben system bounded towards the east by the Ringkøbing-Fyn High and towards the west by the Mid North Sea High (Fig. 1). The half-graben consists of a series of minor NW-SE-trending half-grabens mainly dipping eastwards. The graben formed between the Middle Jurassic and the earliest Cretaceous by the interaction of basement faulting and mobilisation of Zechstein and Triassic(?) salt (Gowers \& Sæbøe 1985; Møller 1986; Cartwright 1987; Korstgård et al. 1993). Locally, stretching factors have been calculated to be up to two (Vejbæk 1992). The faulting and salt mobilisation resulted in a complex configuration of highs and graben features, the most distinct of which have been named (Andersen et al. 1982; Møller 1986; Vejbæk 1986; Japsen et al. 2003, this volume).

Tectonic movements in the Central Graben area have been recognised to have occurred as early as the Permian (Ziegler 1975; Gowers \& Sæbøe 1985); indeed, Rotliegendes strata in the Danish sector record rifting and associated volcanism although not restricted to the Central Graben area (Stemmerik et al. 2000). Zechstein deposits are present in the northern and southern parts of the Danish Central Graben (e.g. the Søgne Basin and the Salt Dome Province) but are probably absent in the central part. There may have been a connection between the southern and northern Permian basins through the Tail End Graben during Zechstein times although evidence (e.g. salt structures) is lacking. Triassic sediments were more widespread and relatively thick Triassic deposits were probably laid down, as indicated by the U-1 well (Jacobsen 1982) and discussed by Vejbæk (1992). Tectonic quies- cence prevailed during the Early Jurassic and a uniform succession of marine mudstones accumulated (Michelsen 1978; Andsbjerg \& Dybkjær 2003, this volume). Middle Jurassic updoming of the Central Graben area (Ziegler 1982) resulted in significant erosion of Triassic and Lower Jurassic sediments. Following Middle Jurassic uplift, a stretching phase caused rapid fault-controlled subsidence, particularly in the Tail End Graben area (Vejbæk 1992). This mainly Late Jurassic rifting ceased during the Early Cretaceous and it has been proposed that subsequent subsidence was controlled by a combination of thermal relaxation and gabbro-eclogite phase transformation, the latter process explaining the increased subsidence rate during the Cenozoic (Vejbrek 1992). Kooi et al. (1991), on the other hand, suggested that increased compressional stresses within the North Sea region were the main cause of accelerated subsidence in the late Cenozoic.

\section{Structural elements}

The complex pattern of the Danish Central Graben has made it necessary to name the most important structural elements (Fig. 1); the following usage is based on Britze et al. (1995) and Japsen et al. (2003, this volume). Towards the east, the Danish Central Graben is bounded by a segment of the Ringkøbing-Fyn High termed the East North Sea High. The eastern part of the graben is subdivided into the Søgne Basin towards the north, the Tail End Graben in the central part, and the Salt Dome Province and the Rosa Basin in the south. Minor elements such as the Poul Plateau constitute the transition between the main boundary fault and the graben itself. Towards the west, the Tail End Graben passes into the Heno Plateau. In the northern part of the graben, a more complex development occurred involving the evolution of a series of grabens, the Arne-Elin, Gertrud and Feda Grabens. The Søgne Basin is separated from the Gertrud Graben by the Mandal High and the Piggvar Terrace. The Mid North Sea High forms the eastern limit of the Danish Central Graben; at the transition this is segmented into the Mads and Inge Highs.

\section{Stratigraphic evolution of the Danish Central Graben}

\section{Pre-Middle Jurassic}

The P-1 well located on the Mads High terminated in Caledonian basement of greenschists. The oldest sedi- 


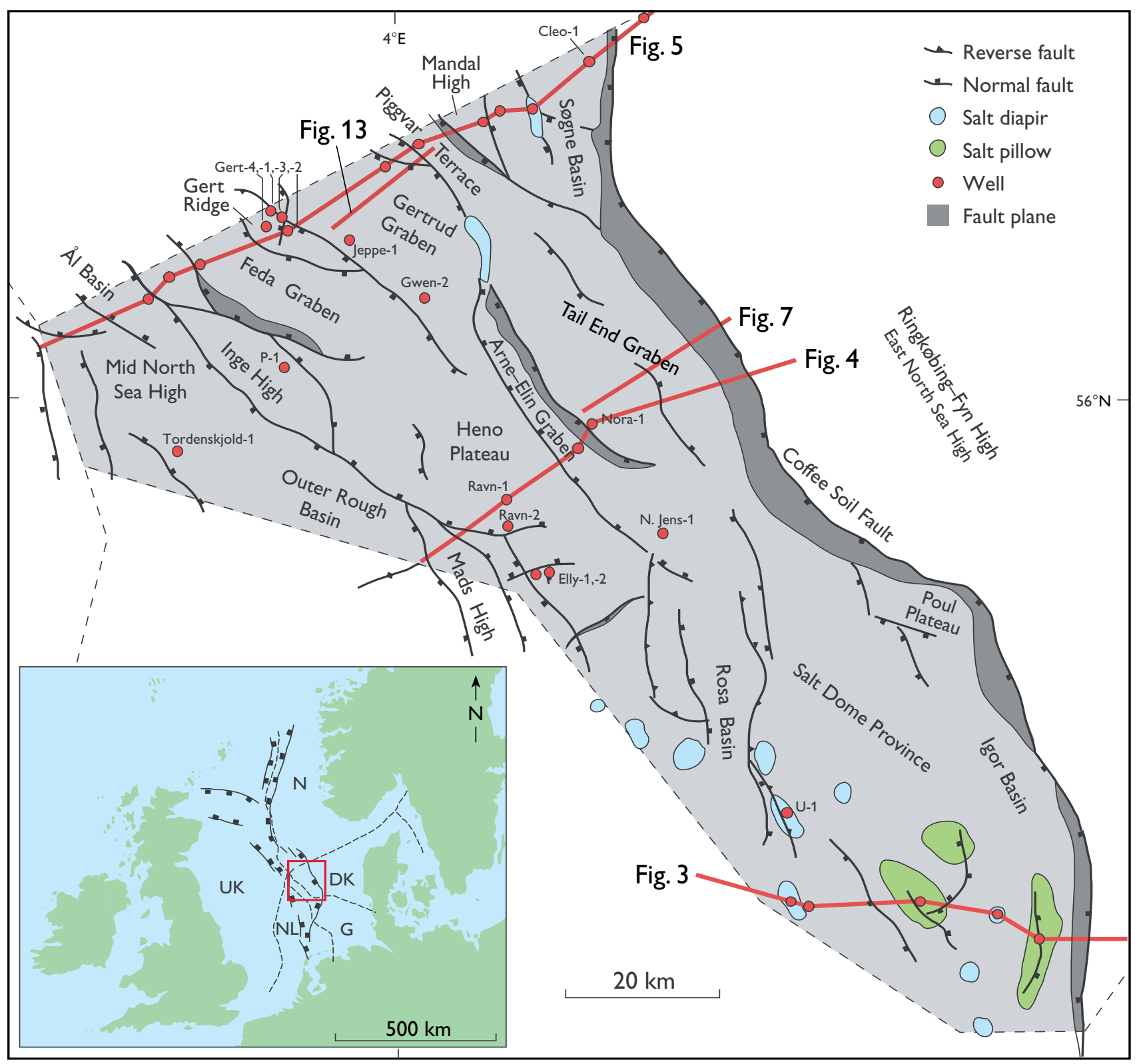

Fig. 1. Location map and structural elements of the Danish Central Graben. Wells referred to in the text are indicated, together with the location of the geosections in Figs 3-5 and the seismic lines in Figs 7, 13. Position of additional wells named on Figs 3-5 is also shown. National sectors of the North Sea: DK, Denmark; G, Germany; N, Norway; NL, the Netherlands; UK, United Kingdom.

mentary deposits known in the Danish Central Graben are of Carboniferous age, as encountered in the P-1 well (Michelsen 1982) and in the Gert-2 and Gert-3 wells. Thick Carboniferous sections are known both south and north of Danish territory (Michelsen 1982) and the Carboniferous is believed to have been distributed over most of the area, but was probably eroded during later tectonic events. The Lower Permian section is characterised by volcanic rocks succeeded by aeo- lian deposits and sabkha sediments of the Rotliegendes Group (Jacobsen \& Larsen 1982; Stemmerik et al. 2000). Transgression of the northern and southern parts of the Danish Central Graben in the Late Permian resulted in the deposition of carbonates and evaporites referred to the Zechstein Group. Triassic sedimentation occurred in basinal areas inherited from the Permian, but elevated areas were also periodically areas of deposition. The Triassic section is dominated by non-marine sandstones 


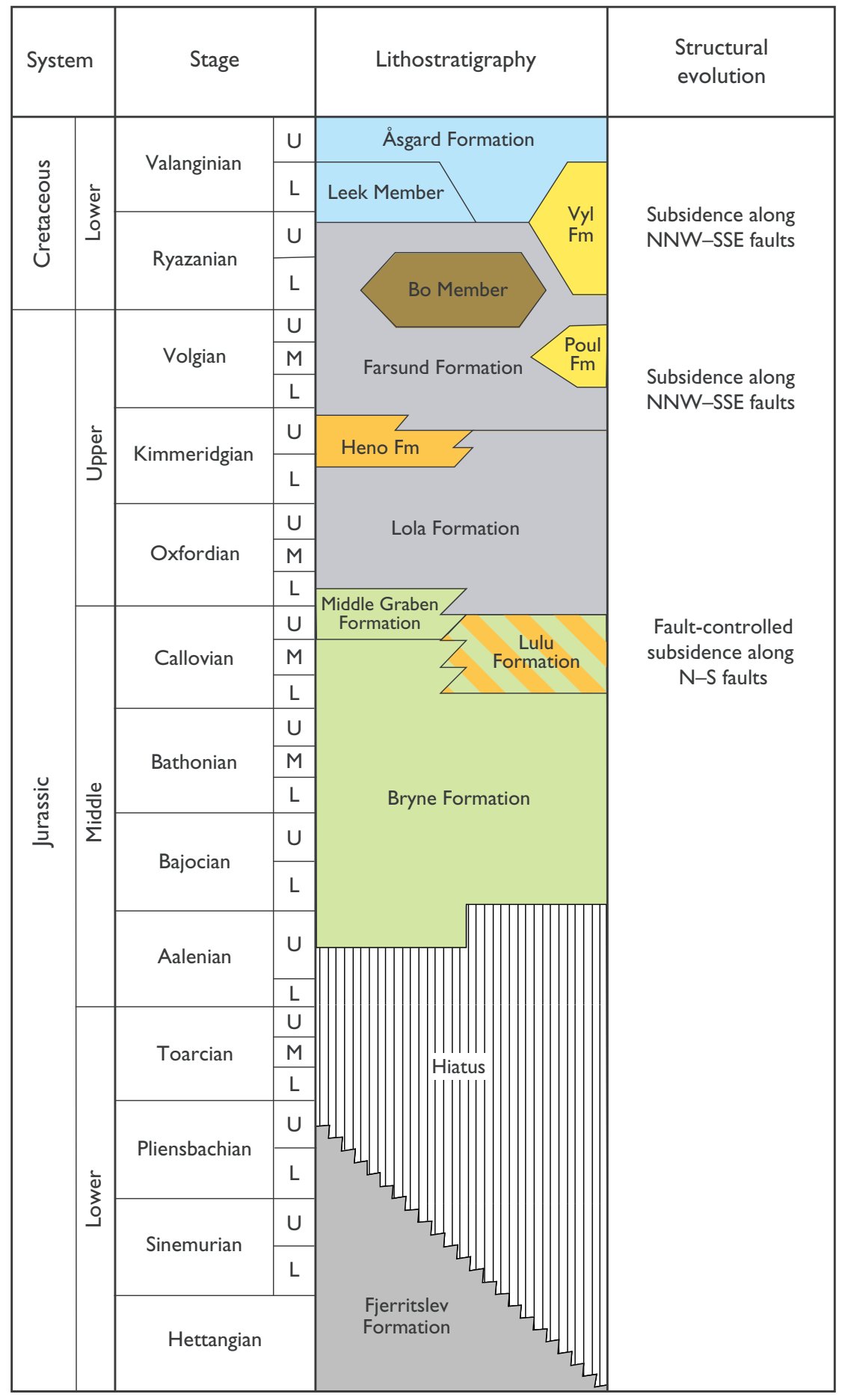

Fig. 2. Jurassic - lowermost Cretaceous lithostratigraphy of the Danish Central Graben (modified from Michelsen et al. 2003 , this volume)

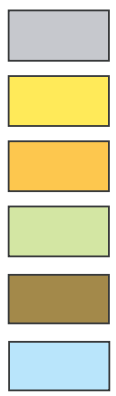

Marine mudstones and siltstones

Submarine fan sandstones and siltstones

Shallow marine sandstones and siltstones

Paralic and non-marine sandstones, siltstones, mudstones and coals

Offshore organic-rich marine shales

Marine calcareous mudstones and marlstones

and shales with subordinate evaporites (Jacobsen 1982) and in some areas is up to $2000 \mathrm{~m}$ thick. A relatively uniform succession of marine shales is believed to have been deposited over most of the Danish North Sea region during the Early Jurassic (Koch et al. 1982; Michelsen et al. 2003, this volume), but most of this was eroded in the Middle Jurassic.

\section{Middle-Late Jurassic}

The collapse of the North Sea Plume (Ziegler 1982; Underhill \& Partington 1993) and graben formation resulted in progressive marine transgression of the area in the Middle and earliest Late Jurassic. Deposition of fluvial, lacustrine, and nearshore sandstones occurred 
during this period, such as the 'Basal Sandstone Unit' in the Norwegian sector of the Feda Graben (Bergan et al. 1989), the Bryne Formation in the Salt Dome Province and the Tail End Graben, and the Bryne and Lulu Formations in the Søgne Basin (Damtoft et al. 1992; Johannessen \& Andsbjerg 1993; Michelsen et al. 2003, this volume; Fig. 2). These sand-dominated formations are succeeded by marine shales of the Lola Formation and sandstones of the Heno Formation. The latter formation has an overall retrogradational stacking pattern although widespread progradation of sands occurred during the Late Kimmeridgian, represented by the upper part of the Heno Formation (the Ravn Member, see Johannessen 2003, this volume; Michelsen et al. 2003, this volume). Following regional flooding in the latest Late Kimmeridgian, a thick mudstone-dominated marine succession (the Farsund Formation) was deposited. The Farsund Formation ranges in age from latest Late Kimmeridgian to Early Ryazanian and is very rich in organic matter at a number of levels; it forms the most important hydrocarbon source rock in the Danish area. Of particular note is the Bo Member within the uppermost part of the Farsund Formation which is an excellent source rock (Ineson et al. 2003, this volume). Turbiditic sandstones have been recognised in several wells in the upper Farsund Formation, at roughly the same stratigraphic level as the organic-rich mudstones of the Bo Member (Damtoft et al. 1992; Andsbjerg \& Dybkjær 2003, this volume).

\section{Data and methods}

The present study is based on all multichannel 2D seismic surveys acquired since 1980 (RTD, SP, DMK, DK, CGD, NP, NH), giving a very dense coverage of the study area. In addition, selected 3D surveys have been utilised in the study. Well information from 43 exploration wells penetrating the Jurassic succession have been used. Well-to-seismic ties have been achieved using the velocity surveys from released wells (Nielsen \& Japsen 1991). The age assignments of the sedimentary succession are based on recent studies (Johannessen et al. 1996; Andsbjerg \& Dybkjær 2003, this volume).

The seismic interpretation is a combination of traditional mapping of distinct reflectors or unconformities and seismic facies analysis. Regionally mappable reflectors have been correlated with the sequence stratigraphic subdivision of Andsbjerg \& Dybkjær (2003, this volume). Seismic facies analysis has been applied to selected seismic sections, incorporating recent idealised models of seismic facies characteristics with respect to the recognition of tectonic systems tracts (e.g. Prosser 1993). The systems tracts have then been correlated to wells, wherever possible, although such correlations often involve major uncertainties since wells are normally located on structural highs where seismic ties are poor. The most important wells used in this study were the Gert-4, Nora-1, and North Jens-1 wells.

\section{Structural evolution}

To illustrate the overall structural framework of the Danish Central Graben, three geosections are presented covering the southern, middle and northern part of the graben, together with an isochore map of the Upper Jurassic succession (Figs 3-6); these illustrations are based primarily on older 2D seismic surveys integrated with borehole data. It must be stressed, however, that the structural interpretation presented here is based on new high resolution seismic data, such as that shown in Figure 7 and the study of the 3D seismic data from the Gert area. Consequently, there are some discrepancies between the seismic units displayed on the geosections and the rift events proposed in this paper.

In general, accumulation of the thickest Jurassic succession was associated with marked subsidence along the Coffee Soil Fault. This subsidence pattern was modified by salt movements during the Jurassic, especially in the southern part, the so-called Salt Dome Province. A relatively thick Jurassic interval is also seen in the Gertrud and Feda Grabens (Figs 5, 6). This present configuration of the graben fill is the result of successive fault activity resulting in combined fault-controlled subsidence of half-grabens and subsidence/uplift related to salt movements. From the Middle Jurassic to the earliest Early Cretaceous, three tectonic pulses are recognised: (1) Callovian to Early Oxfordian fault-controlled subsidence, concentrated along N-S-striking faults; (2) a latest Late Kimmeridgian to Early Volgian pulse, characterised by a distinct shift to subsidence along NNW-SSE-trending faults; (3) a final pulse (Ryazanian) also involving fault-controlled subsidence along NNW-SSE-striking faults.

\section{Tectonic pulse 1}

The first pulse, from the Callovian to the Early Oxfordian, was characterised by mainly fault-controlled subsidence along N-S-striking faults. Such faults include segments 


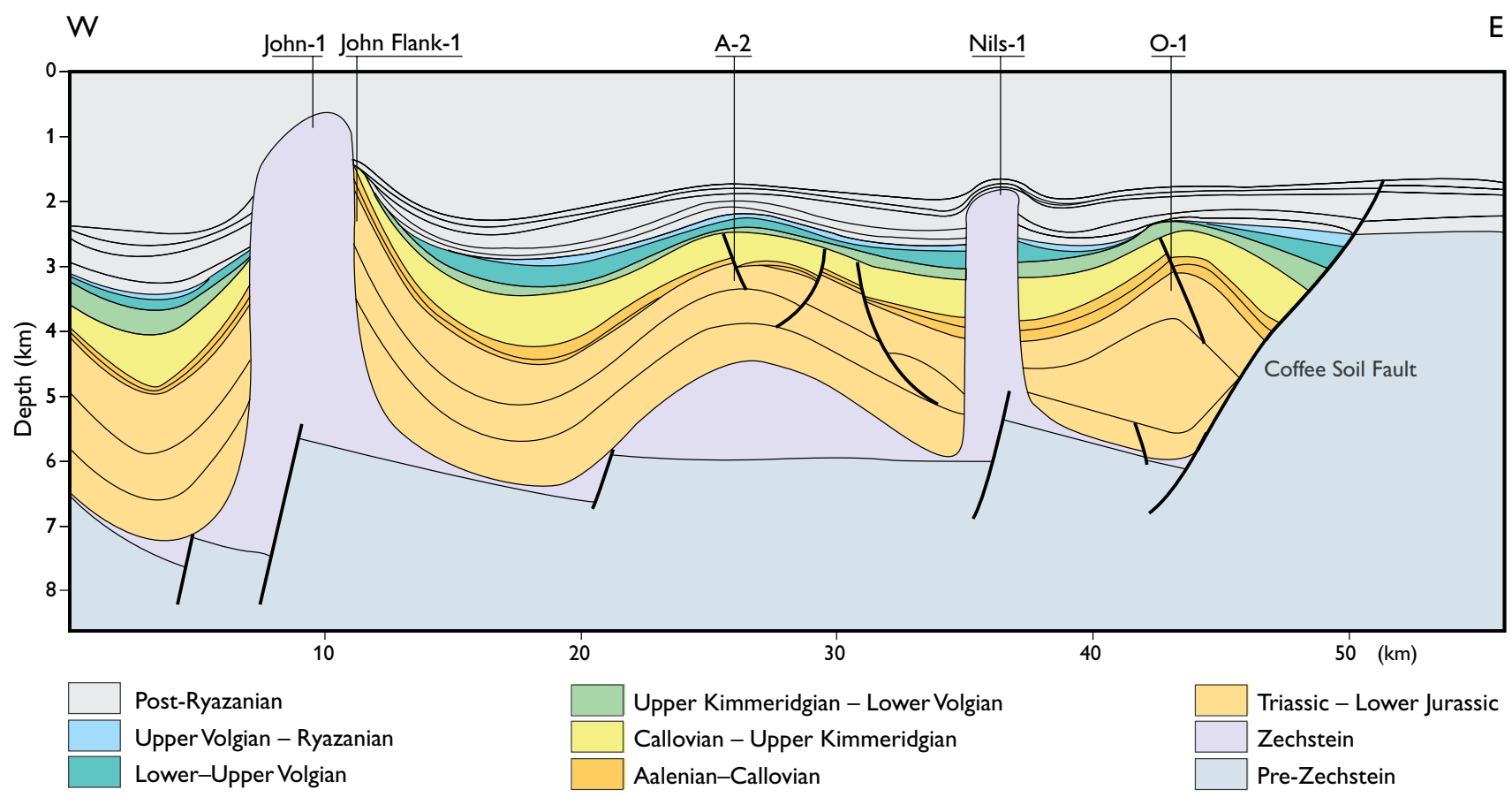

Fig. 3. Geosection of the Salt Dome Province (for location, see Fig. 1).

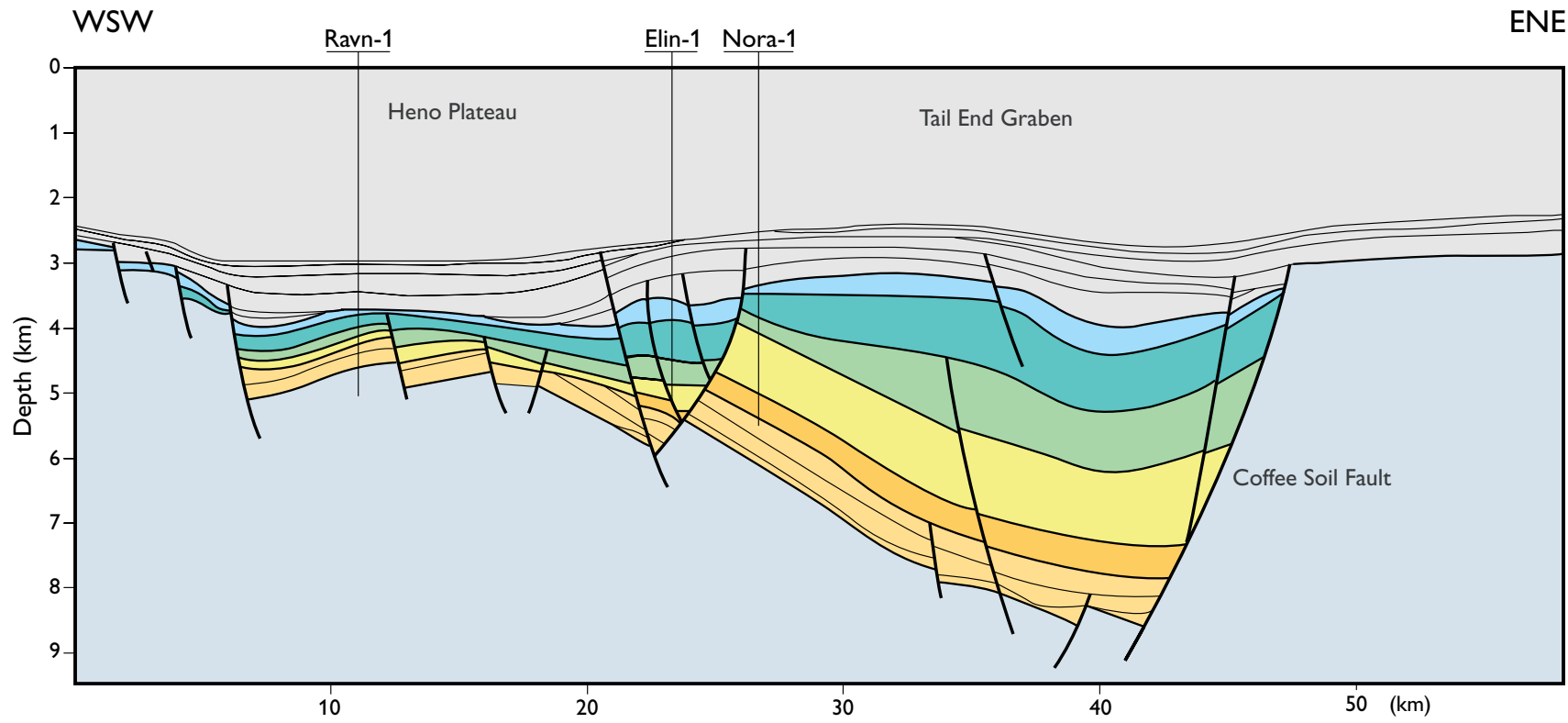

Fig. 4. Geosection of the Tail End Graben and the Heno Plateau (for location, see Fig. 1; for legend, see Fig. 3).

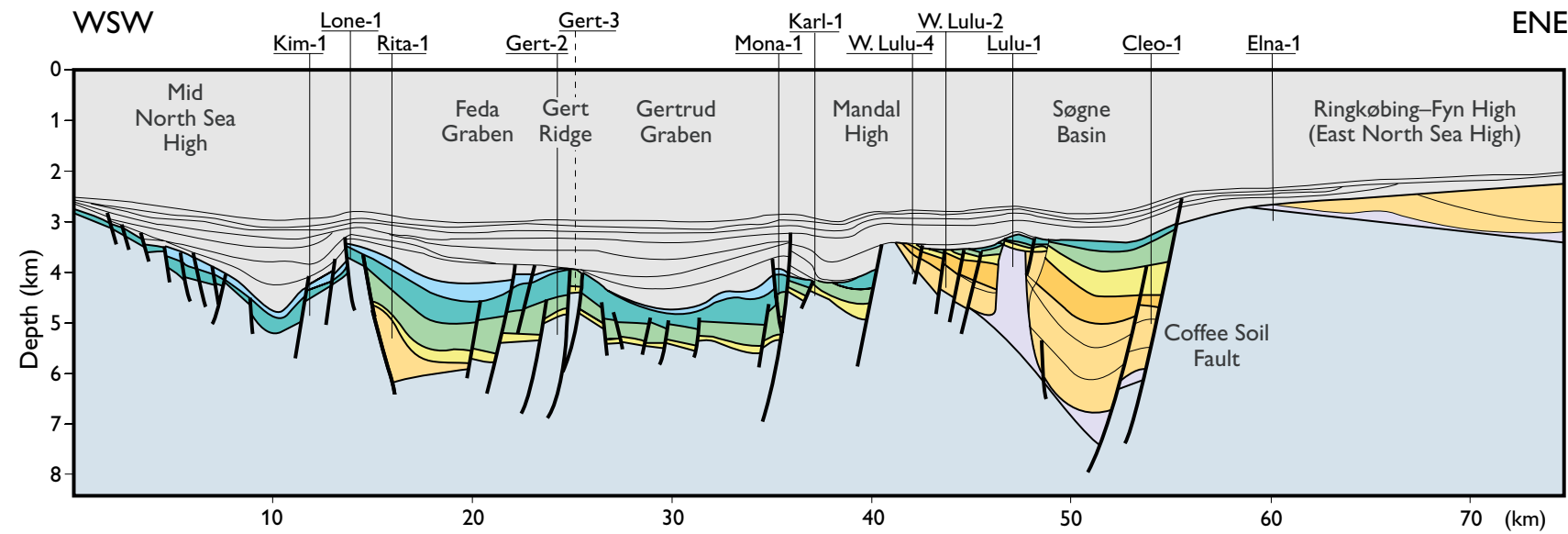

Fig. 5: Geosection of the northern part of the Danish Central Graben (for location, see Fig. 1; for legend, see Fig. 3). The Gert-3 well lies just north of the section and is projected into the line of section. 


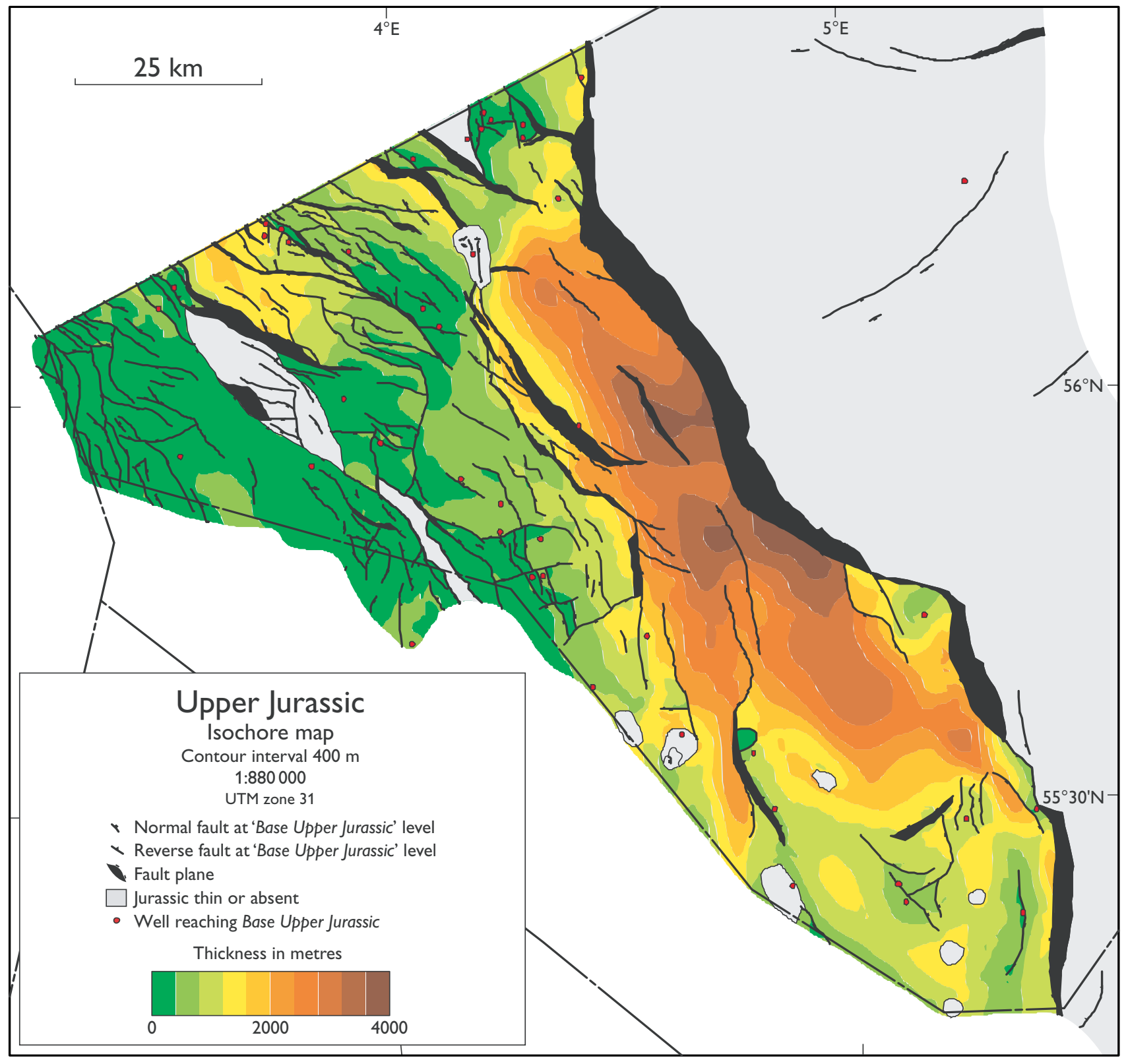

Fig. 6: Isochore map of the Upper Jurassic succession of the Danish Central Graben (from Japsen et al. 2003, this volume).

of the Coffee Soil Fault, N-S-striking faults within the Tail End Graben (Figs 7, 8), and faults in the north-western area around the Gert Ridge (Rasmussen 1995). In the Tail End Graben (Fig. 7), the seismic reflection pattern records the response of the sedimentary system to different stages in rift evolution; two discrete tectonic events can be identified in this area (tectonic pulses 1 , 2). The base of the first event is characterised by a distinct angular unconformity, created by erosion of the footwall (Fig. 7). Above the unconformity, two wedgeshaped reflection packages are ascribed to the first tectonic pulse; they are interpreted to reflect different stages in the rotation of the fault block. As illustrated in the flattened section (Fig. 9), the lower wedge-shaped interval (rotational tilt package 1) is characterised by a low amplitude and discontinuous reflection pattern, which grades upwards into a high amplitude, continuous and wedge-shaped dipping reflection pattern that can be followed over the entire tilted fault block area. The upper wedge (relaxation package 1) is characterised by a low amplitude, gently-dipping parallel and sub-parallel seismic reflection pattern, showing regular onlap onto the underlying interval. Little indication 

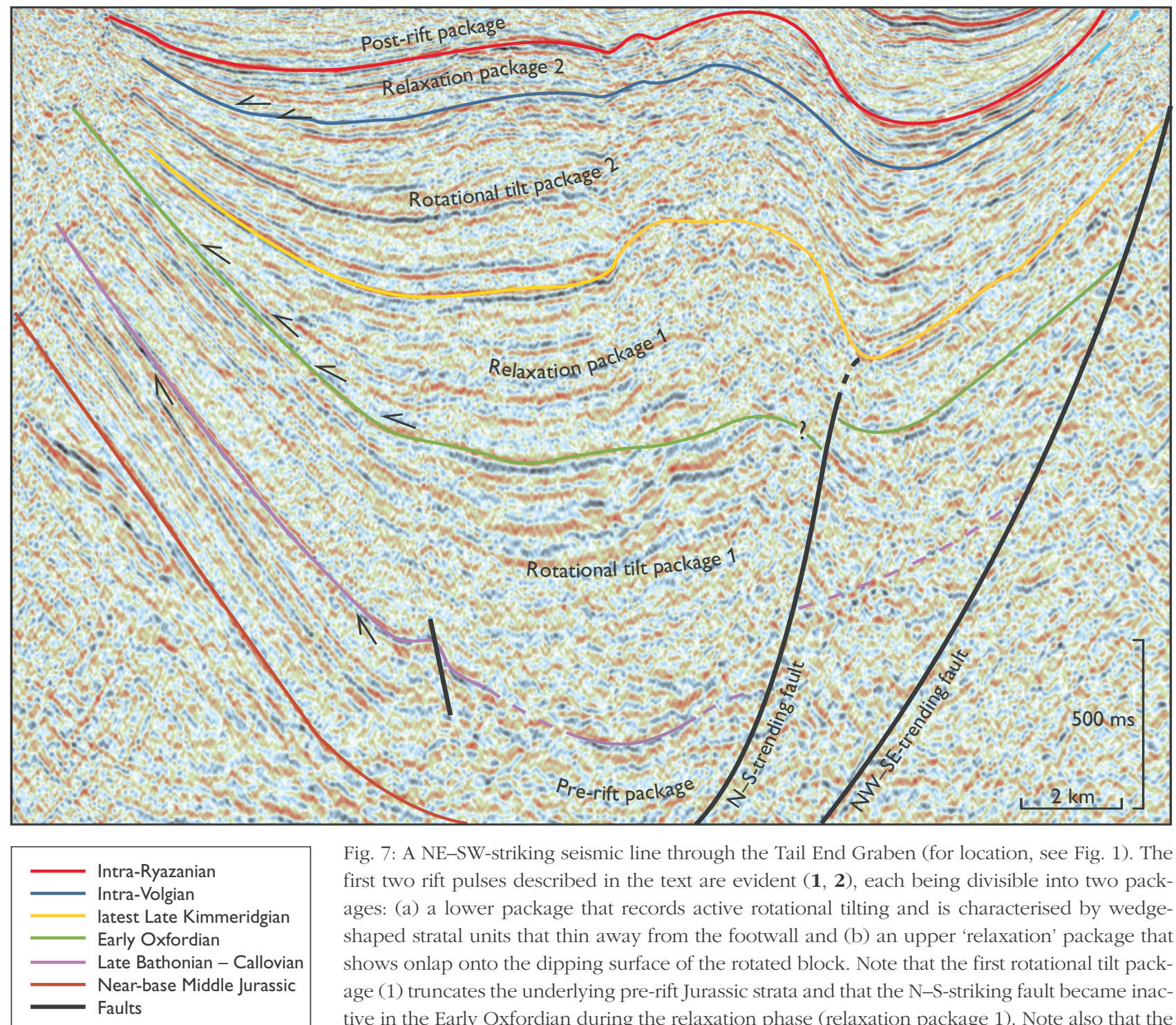

Fig. 7: A NE-SW-striking seismic line through the Tail End Graben (for location, see Fig. 1). The first two rift pulses described in the text are evident $(\mathbf{1}, \mathbf{2})$, each being divisible into two packages: (a) a lower package that records active rotational tilting and is characterised by wedgeshaped stratal units that thin away from the footwall and (b) an upper 'relaxation' package that shows onlap onto the dipping surface of the rotated block. Note that the first rotational tilt package (1) truncates the underlying pre-rift Jurassic strata and that the N-S-striking fault became inactive in the Early Oxfordian during the relaxation phase (relaxation package 1). Note also that the third pulse of block rotation cannot be demonstrated in this area.

of thickening of individual units can be recognised within this package.

The seismic reflection pattern can thus be interpreted to reflect episodic block rotation during rifting. The lower wedge-shaped reflection pattern, showing thickening of individual stratal units towards the down-tilted area reflects deposition during active block rotation (Prosser 1993, fig. 8). The overlying wedge, showing a parallel to sub-horizontal reflection pattern, is interpreted to represent passive fill during tectonic relaxation or a period during which the rate of block rotation was strongly reduced and the sediment mainly filled the topographic low created during the main rift pulse. The prominent onlap of the relaxation package onto a dip- ping surface, however, indicates that major tilting must have occurred prior to deposition of the sediments. It is therefore possible that the rift climax was characterised by non-deposition or that syn-rift sediments were confined only to the lows, where seismic resolution is poor in this area. Measurements of Recent tilting rates of fault blocks in Greece (Gawthorpe et al. 1994) show that the process of active tilting can be very rapid, up to $5 \mathrm{~mm} /$ year $=5000 \mathrm{~m} / \mathrm{Ma}$. Deposition of the Jurassic - lowermost Cretaceous succession described above occurred over a period of $29 \mathrm{Ma}$; given a total thickness of c. $4000 \mathrm{~m}$, the average tilt corresponds to $137 \mathrm{~m} / \mathrm{Ma}$, which is significantly less than that suggested by Recent measurements. It is thought likely, 


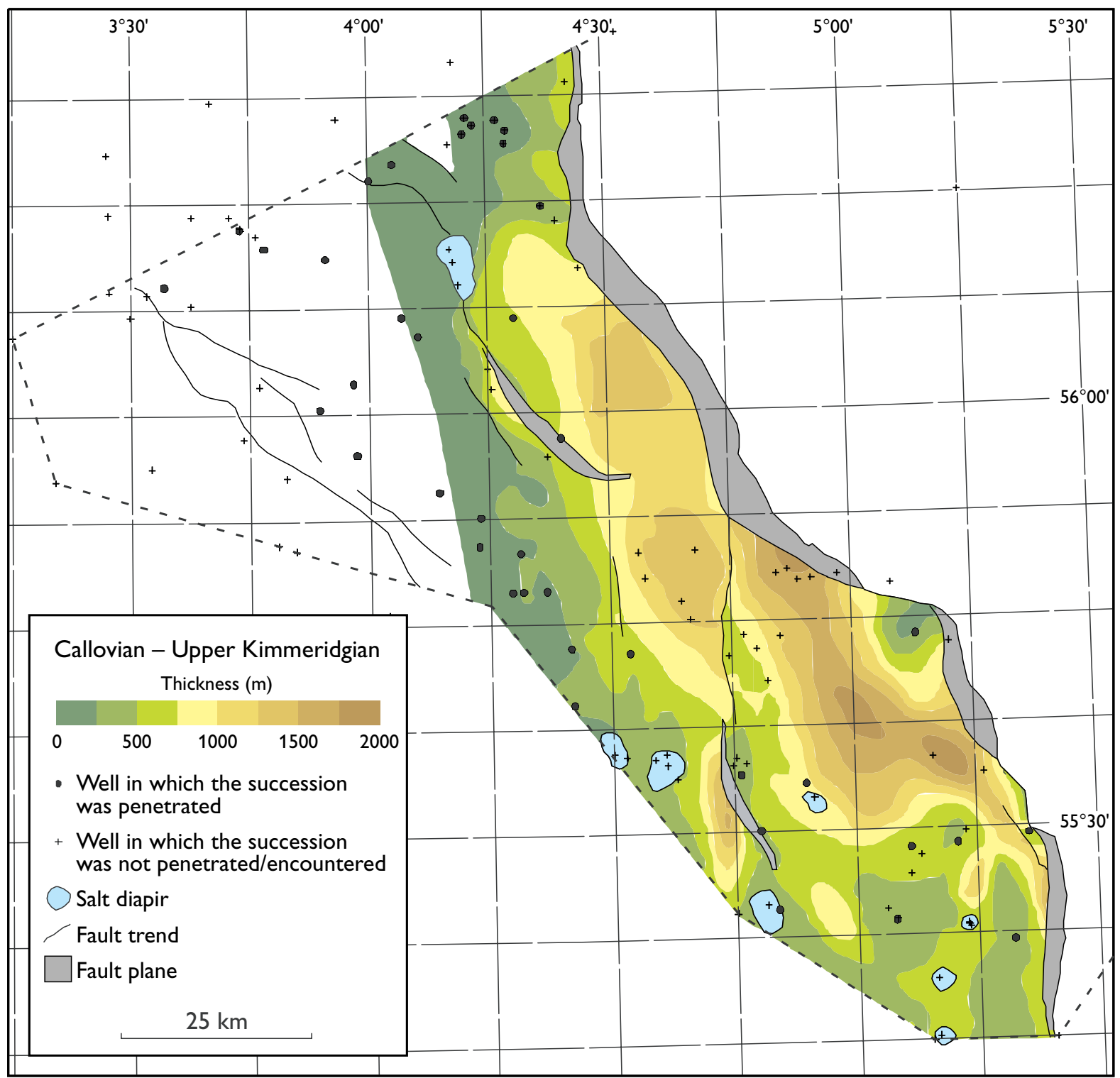

Fig. 8. Isochore map of the Callovian - Upper Kimmeridgian succession showing the main faults that were active in this period. Note firstly the influence of $\mathrm{N}-\mathrm{S}$-striking faults, which were active during the Callovian and Early Oxfordian, and secondly that depocentres are close to the faults.

therefore, that the main phase of tilting was so fast that sedimentation never managed to fill the space created. Consequently, rift-climax deposits are volumetrically insignificant and not resolvable on seismic data.

The faults of the first rift pulse were active during the deposition of the Bryne and Middle Graben Formations in the Salt Dome Province and the Bryne and Lulu Formations in the Tail End Graben and Søgne Basin (J. Andsbjerg, personal communication 1998). The relaxation package is represented by the Lola Formation in the above-mentioned depocentres. The
Lola Formation was also deposited on the Heno Plateau where it is succeeded by the sand-dominated Heno Formation. In the Feda Graben, the Gert Member (Heno Formation), the Lola Formation and the Ravn Member (Heno Formation) together represent the early graben fill corresponding to deposition during tectonic quiescence (Johannessen et al. 1996).

Biostratigraphic data from wells that encountered the sediments deposited during the first tectonic pulse suggest that the faults were probably active from ?Middle Jurassic times (Andsbjerg \& Dybkjær 2003, this volume) 


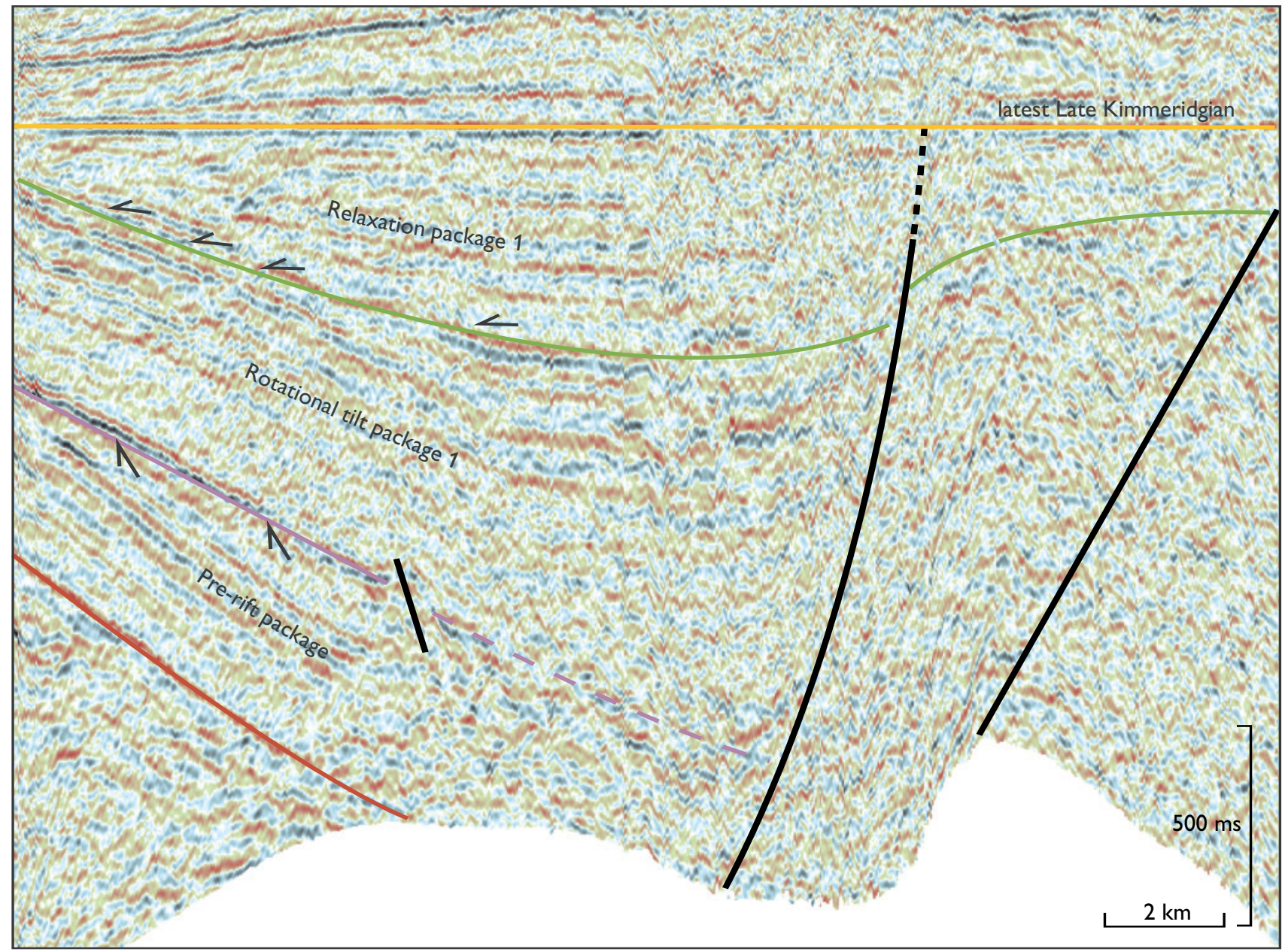

Fig. 9. The central portion of the seismic section shown in Fig. 7, flattened on the boundary between the first two rift pulses (late Late Kimmeridgian surface). The figure thus shows the stratal pattern of the first rift pulse. For key to reflectors, see Fig. 7 .

although the age and duration of the fault activity is difficult to determine accurately. However, in the Tail End Graben the unconformity illustrated in Figure 7 probably truncates Middle Jurassic lacustrine sediments of the Bryne Formation and is overlain by rotational tilt deposits of the uppermost Bryne and Lulu Formations indicating onset of rifting in the Late Bathonian Callovian (Middle Jurassic) and cessation in the Early Oxfordian (Late Jurassic).

The tectonic pattern characterised by the N-S-striking faults probably represents reactivation of older faults. Most of the half-grabens formed during this phase were tilted towards the east, although the Feda Graben formed as a westwards-dipping half-graben bounded by the Mid North Sea High towards the west. The Gertrud Graben was a later feature (see below) and at this time formed a plateau region that was continuous with the Heno Plateau separating the Feda Graben from the Tail End Graben. Although acting as a plateau, minor faulting probably accompanied the major fault activity in the graben structures.

\section{Tectonic pulse 2}

Following a period of tectonic quiescence, discrete subsidence occurred along NNW-SSE-trending faults (Figs 7, 10) during the latest Late Kimmeridgian and Early Volgian. This resulted in displacement along the Coffee Soil Fault from the Salt Dome Province in the south and further northwards. However, the northernmost segment of the Coffee Soil Fault, which previously bounded the Søgne Basin, became inactive and displacement occurred along the NW-SE-striking fault just west of the Søgne Basin (Fig. 10). Increased thicknesses within the Søgne Basin, as indicated on the Late Kimmeridgian - Early 


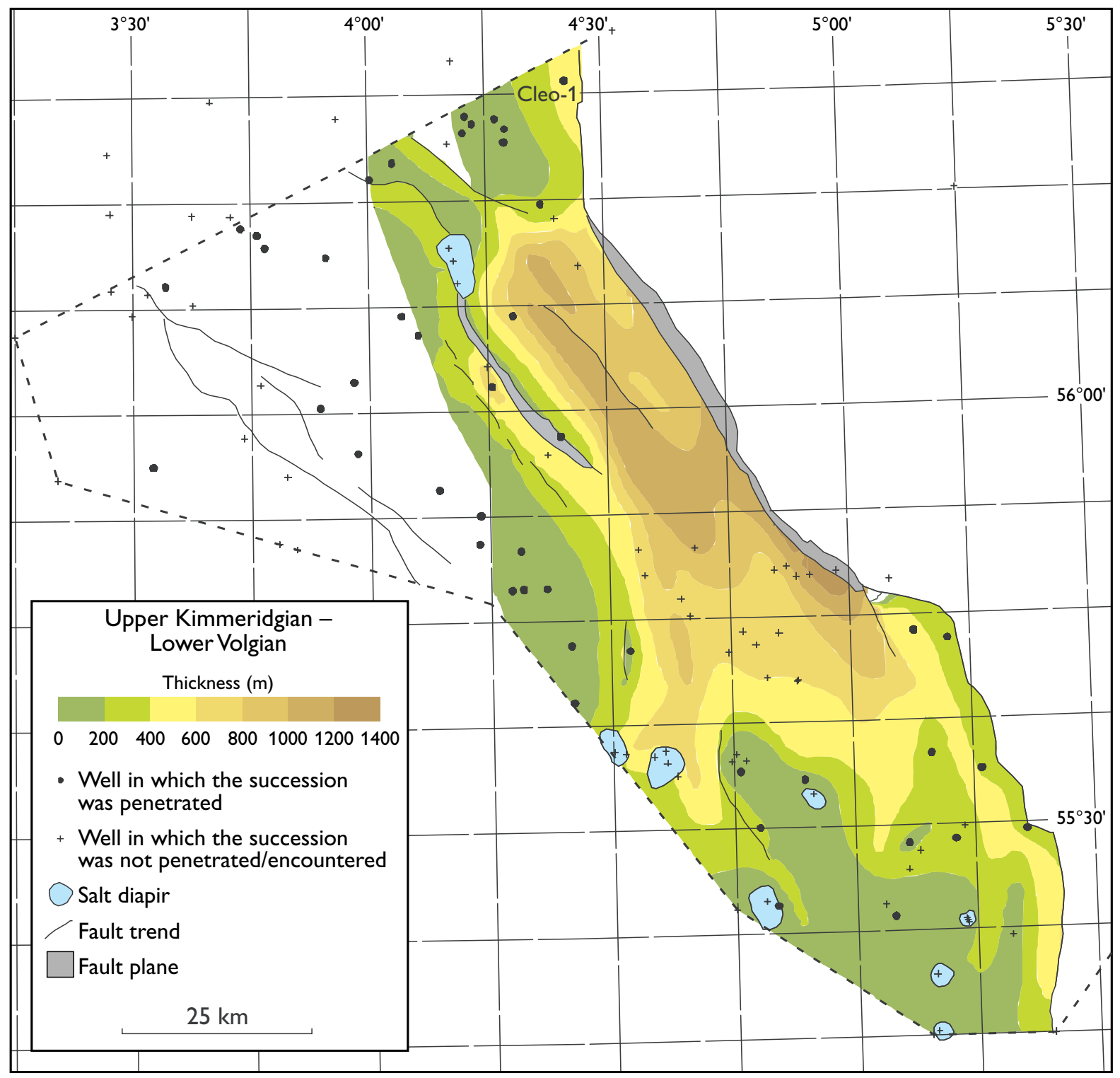

Fig. 10. Isochore map of the Upper Kimmeridgian - Lower Volgian succession. Note that the depocentres have shifted to occur along NW-SE-trending faults in the Tail End Graben and Gertrud Graben (cf. Fig. 8). The depocentres still lie close to the faults.

Volgian isochore map (Fig. 10), are documented by the Cleo-1 well which penetrated a Lower Volgian succession. However, seismic data reveal that this Volgian succession represents a tectonic relaxation package that was preserved at the Cleo- 1 well location as a result of later tilting of the Søgne Basin (during tectonic pulse 3). During the second pulse, fault-controlled subsidence occurred in the Arne-Elin Graben (Fig. 11) and along the faults bounding the Feda and Gertrud Grabens (Fig. 5). The occurrence of fault-controlled segmentation of the Heno Plateau is demonstrated by the evidence of increased subsidence at the site of the Ravn- 2 well compared with the nearby Ravn-1 site (Fig. 11; Andsbjerg \& Dybkjær 2003, this volume). Segmentation of the Mid North Sea High was also initiated at this time, resulting in the formation of the Mads and Inge Highs and the basins west of the Mads and Inge Highs (Mackertich 1996). In the Tail End Graben, the depocentre shifted basinwards reflecting the influence of salt withdrawal concurrent with fault activity. During the tectonic quiescence that followed the second tectonic pulse, the relief created was passively infilled by the upper Farsund 


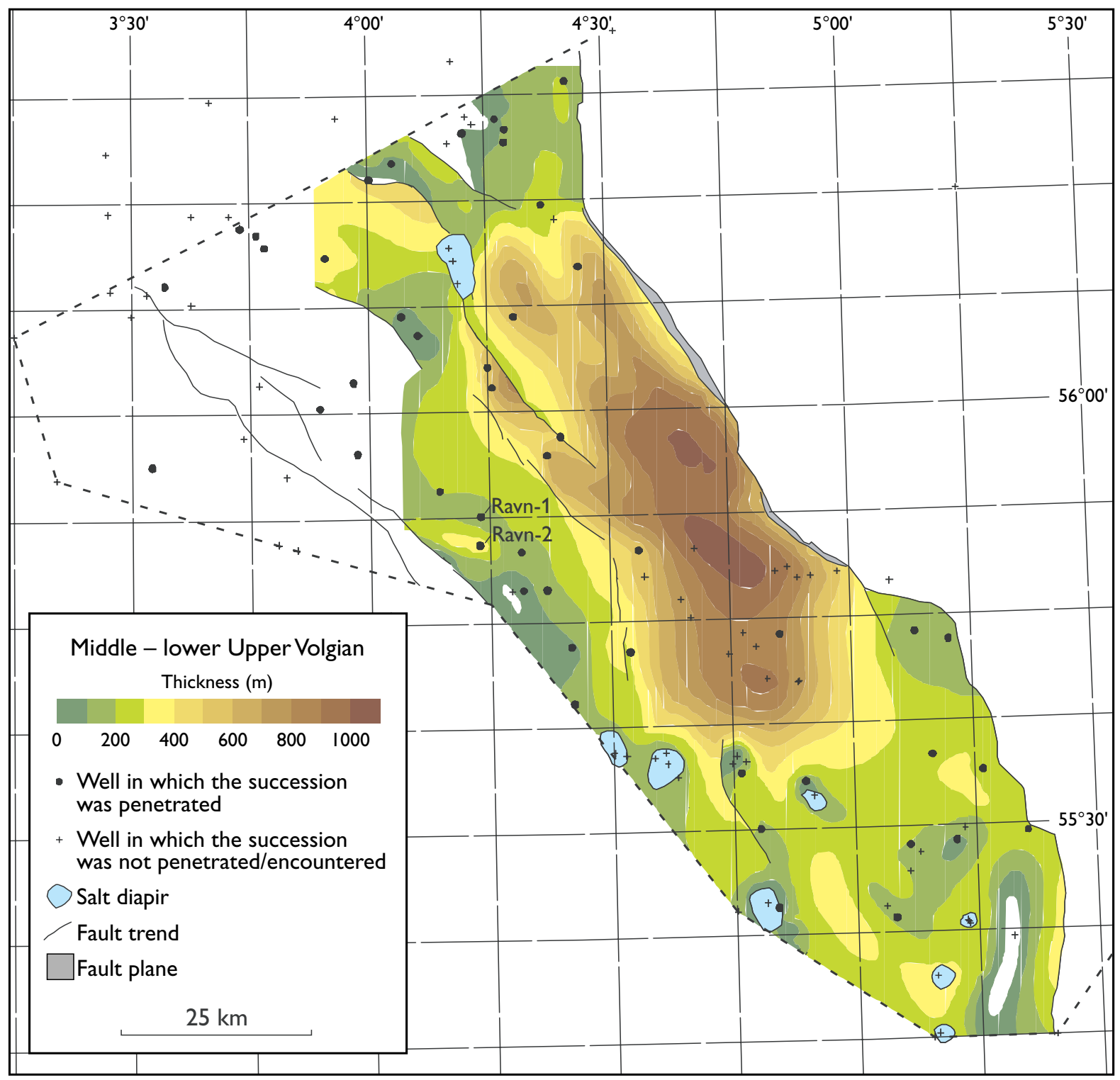

Fig. 11. Isochore map of the Middle and lower Upper Volgian succession. Note the displacement of the depocentres away from the master fault.

Formation, including the organic-rich mudstones of the Bo Member (Fig. 12).

\section{Tectonic pulse 3}

The third and final tectonic pulse in the formation of the Danish Central Graben occurred in the midRyazanian (Early Cretaceous). Rotation of fault blocks and deep erosion on footwall crests resulted in the formation of a distinct angular unconformity which is best seen in the northern part of the graben where the influ- ence of salt movements was insignificant (Fig. 13). The age of this event is poorly constrained, but Upper Volgian - Lower Ryazanian organic-rich sediments of the upper Farsund Formation (Bo Member) are rotated on the Heno Plateau (Ravn-2) and in the Gertrud Graben (Gwen-2 and Jeppe-1 wells) suggesting that the tectonic pulse post-dates these Lower Ryazanian deposits. The topography formed during this pulse was filled by an onlapping Lower Cretaceous succession (Cromer Knoll Group). The lowermost sediments of this group were deposited in latest Ryazanian - Early Valanginian times in this area (Vejbæk 1986), thus suggesting that this 


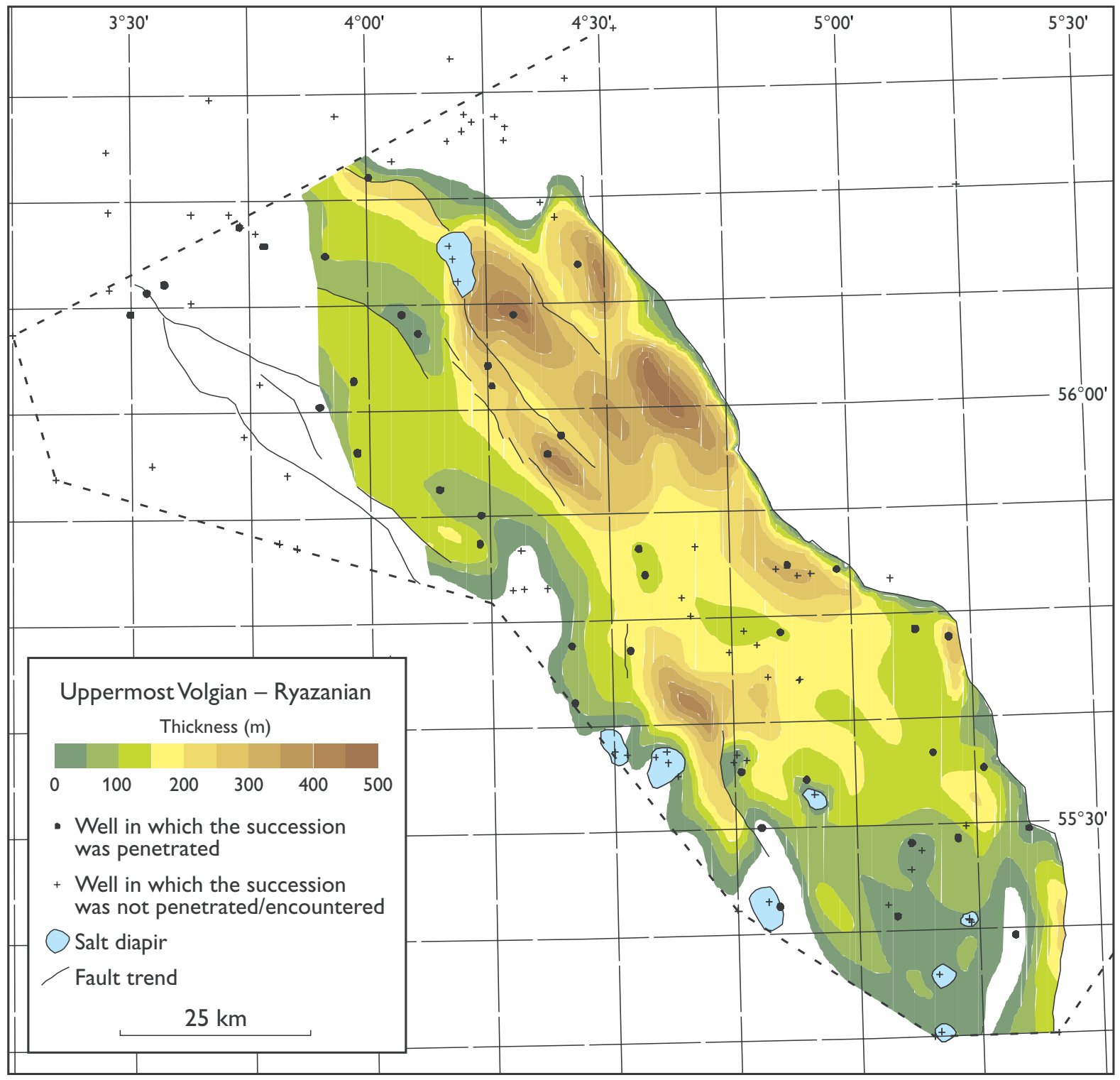

Fig. 12. Isochore map of the uppermost Volgian - Ryazanian succession.

third tectonic pulse occurred in the mid-Ryazanian. Salt tectonics were involved in this phase, especially in the Feda Graben where salt movements began in the Volgian. The basinwards shift of depocentres in the Tail End Graben also reflects involvement of salt in this part of the Danish Central Graben (Fig. 12). The extensional tectonic pattern during this phase, however, resulted in local compression between different blocks; this effect was most marked between the two opposite-dipping Feda and Gertrud Grabens where the Gert Ridge was formed (Rasmussen 1995). It is uncertain whether this local thrusting was the result of strike-slip movements or local compensation between two subsiding blocks. Strike-slip movements have been suggested for the formation of the Arne-Elin Graben (Clausen et al. 1996). The existence of local thrusting in the Late Jurassic has also been suggested by Gowers et al. (1993) for the Norwegian Central Graben.

\section{Regional graben evolution}

The three-fold evolution of the Danish Central Graben described above is comparable in many respects to the 


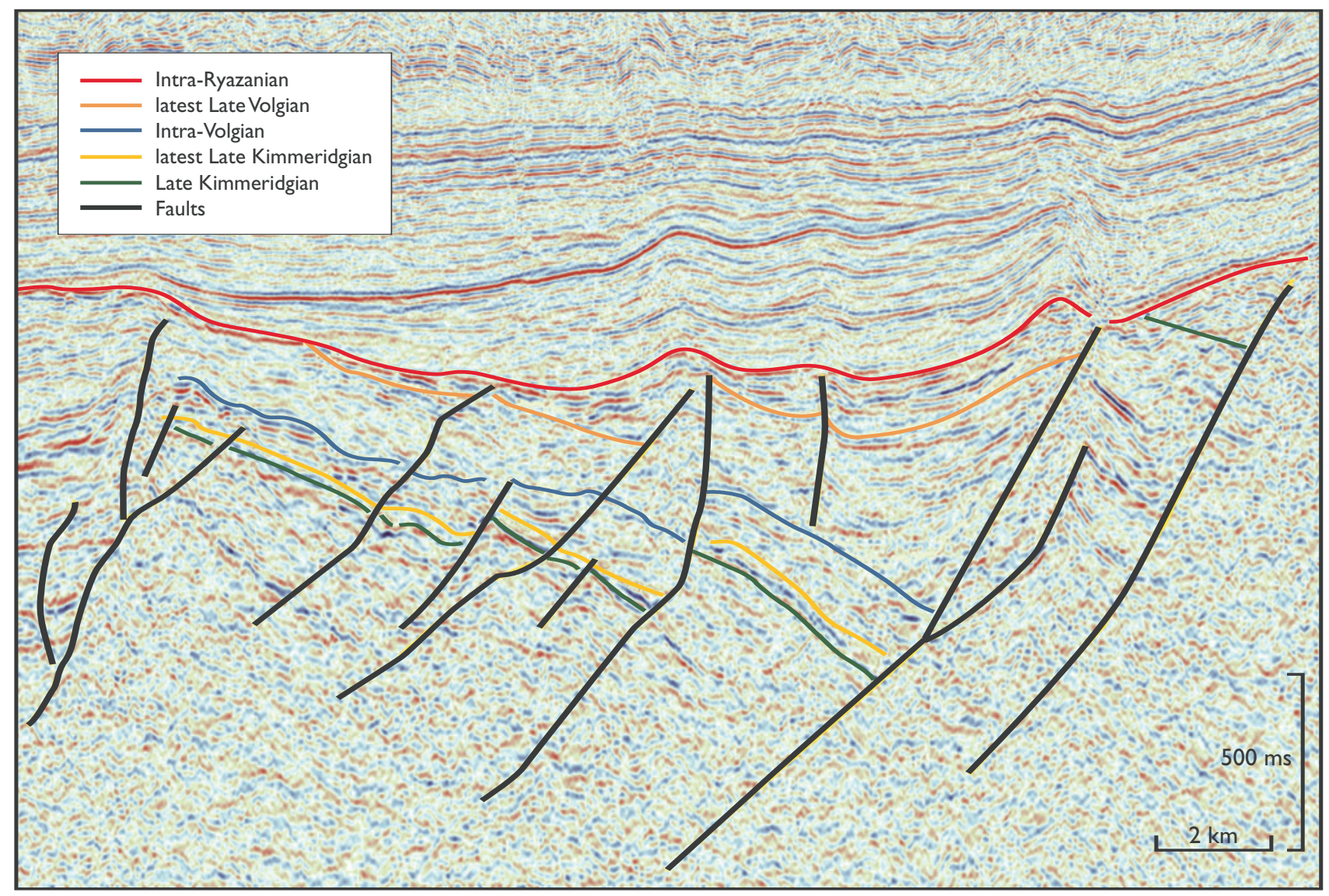

Fig. 13: Seismic section from the Gertrud Graben (for location, see Fig. 1) showing the result of intense tilting of fault blocks during the third and final tectonic pulse in the mid-Ryazanian. Note the prominent onlap at the base of the Cromer Knoll Group (?Upper Ryazanian - Albian) indicating deposition after rotation of fault blocks. The period of fault block rotation was thus short-lived as indicated by onlap of ?Upper Ryazanian sediments in topographic lows (towards the NE).

development of the southern Norwegian sector of the Central Graben, as described by Gowers et al. (1993). The similarities involve not only the timing of tectonic pulses but also the fault trends along which active subsidence occurred. However, the earliest Cretaceous (mid-Ryazanian) event, involving tilting of minor fault blocks within former half-grabens, is probably better constrained in areas with insignificant salt tectonics, such as the northern part of the Danish area.

\section{Discussion}

\section{Structural evolution and sedimentation}

The structural evolution of a basin results both in the creation of accommodation space for the sedimentary fill and in the elevation of potential sedimentary source areas. The development of the sedimentary succession with respect to different tectonic pulses or phases in graben systems has been described by many workers, including Surlyk (1989), Prosser (1993), Nøttvedt et al. (1995), Ravnaas et al. (1997), Rasmussen et al. (1998) and Ravnaas \& Steel (1998). These papers deal with the sedimentary stacking patterns that result from the different stages in the rift evolution focusing on changes in accommodation space and variation in sediment supply. In addition, sequence stratigraphic analysis may provide a tool for stratigraphic and spatial lithological prediction within a rift basin based on the response of the system to relative sea-level changes. However, in a complex rift basin such as the Danish Central Graben, which evolved through three tectonic pulses along different fault trends, prediction of the distribution of potential reservoir facies within the basin is difficult and an understanding of the structural framework is of critical importance. 


\section{Deposition during active block rotation}

The rotational package of the first rift pulse (Fig. 7) is represented by the fluvial deposits of the uppermost Bryne and Lulu Formations in the northern part of the Danish Central Graben and by the uppermost Bryne Formation and the Middle Graben Formation in the southern part. During deposition of these formations, the drainage systems were transverse (Andsbjerg 2003, this volume) such that fluvial sands were concentrated in the elevated areas and lacustrine or marine finegrained sediments accumulated in the deeper parts on the hangingwall blocks. It is therefore not anticipated that significant fluvial sands were deposited adjacent to the master fault, as suggested for axial-trending fluvial sandstones (Alexander \& Leeder 1987).

On the Mid North Sea High, in the westernmost part of the Danish territory, only one released well was available at the time of writing, namely the Tordenskjold-1 well. This well did not encounter reservoir sands in the Jurassic succession, but in the British sector, immediately west of the Danish area, shallow marine reservoir sandstones of relatively high quality are known in the Fife Field (Mackertich 1996). These sandstones, informally named the 'Fife Sandstone Formation', were deposited on a slowly subsiding shelf during Early to Middle Volgian times thus representing the rotational tilt package of the second rift pulse. The thickness variation of this formation was primary controlled by NNW-SSE-trending faults, and well data show sandstone thickening and improvement in reservoir quality towards the main fault. On the footwall crest, a much thinner Fife sandstone succession has been encountered. This sandstone was deposited during the second tectonic pulse and the thickest and best-developed sandstones were laid down on the hangingwall of the fault.

\section{Deposition during tectonic quiescence}

In the Gert and Elly Fields, the reservoir sandstones belong to an overall onlapping succession deposited during tectonic quiescence after the first rift pulse (Fig. 7; see also fig. 13 in Johannessen et al. 1996). These sandstones were deposited in nearshore depositional environments and unconformably overlie either Middle Jurassic continental sediments or older rocks. Coastal sands were therefore successively deposited on elevated areas in the basin and at the basin margin. In the Gert area, reservoir-quality sands were deposited in the
Late Kimmeridgian adjacent to $\mathrm{N}-\mathrm{S}$-striking faults related to the first rift pulse. These faults controlled the distribution of the sand during deposition suggesting that differential subsidence across certain $\mathrm{N}-\mathrm{S}$ faults persisted into the Kimmeridgian despite becoming regionally inactive in the Oxfordian. Younger NW-SE-trending faults subsequently created the Gert Ridge (Søderstrøm et al. 1991; Sundsbø \& Megson 1993; Rasmussen 1995) and defined the structural closure that hosts the Gert Field. Appraisal wells drilled on the Gert structure have to date been located on the structural high and the thickness of reservoir section encountered has been disappointing. The influence of the N-S-striking fault should be incorporated in future field development models and may help in predicting the distribution of these reservoir sandstones. The Gert area, furthermore, demonstrates the close relationship between a local sediment source area and deposition of a thick reservoir section. Uplifted Carboniferous fluvial sandstones in the footwall probably formed the source for the Gert Member sandstones in this area. This is suggested by the presence of Carboniferous sandstones beneath the Upper Jurassic succession in the Gert-2 well and the abundance of reworked Carboniferous palynomorphs in the Gert Member in the Gert-1 well (K. Dybkjær, personal communication 1997).

Another interesting aspect related to the development of the Lola and Heno Formations is that due to the overall relative sea-level rise during the Late Oxfordian and Kimmeridgian, progradation during tectonic quiescence was muted; the progradational pulse observed in the uppermost part of the Heno Formation was probably related to sea-level stillstand or fall rather than to the tectonic evolution of the basin.

The second tectonic pulse resulted, as for the first pulse, in the formation of a basin topography that was passively filled during the following period of tectonic quiescence. However, in this case the Danish Central Graben was fully submerged and marine conditions prevailed, with the exception of marginal areas of the Ringkøbing-Fyn High and the Mid North Sea High. The Upper Volgian - Ryazanian turbidites encountered in the Jeppe-1 and Iris-1 wells represent a relatively untested play within the Danish Central Graben. The turbidites have been interpreted as passive fill succeeding the second tectonic pulse (Rasmussen et al. 1999). As these turbidites were deposited in a basin with marked relief, it is anticipated that the sands were concentrated in the axial parts of the subbasins, as seen for example in the Pendle Grit of the British Namurian (Collinson 1988). The third and final tectonic pulse resulted in block rotation 
and marked erosion on footwall crests. In the northern and western part of the Danish Central Graben, the sand-rich Heno Formation, the Lower-Middle Volgian nearshore sandstones on the Mid North Sea High (Mackertich 1996) and Upper Volgian - Ryazanian turbidites were eroded. Reworked coarse-grained sediments may therefore have been deposited within lows formed in association with this tectonic pulse and may represent a Lower Cretaceous sandstone play that so far has not been tested in the Danish Central Graben.

\section{Concluding remarks}

It appears therefore that the tectonic framework is very important for the distribution and quality of reservoir rocks. Under terrestrial conditions, in the Middle Jurassic, the reservoir sands accumulated on the upper and middle parts of the hangingwall slope. In the lower part of the hangingwall slope and adjacent to the master fault, sandstones are intercalated with, and diluted by, lacustrine or marine shales. In periods with nearshore depositional environments, fault trends acted either as a temporal or as a spatial controlling element on the sedimentary fill, but here the best reservoir quality is observed near the master fault, as seen, for example, in the Gert area. The structural morphology is also relevant to prediction of the distribution of turbidite sandstones, which were probably deposited within lows on the hangingwall.

\section{Sea-level changes}

In addition to the tectonic framework, sea-level variation is also believed to have controlled the location of sandstones. A sea-level curve for the Middle Jurassic to Lower Cretaceous succession in the Danish Central Graben has been constructed by Andsbjerg \& Dybkjær (2003, this volume). Particularly low sea levels are interpreted to have occurred during the Kimmeridgian; Johannessen \& Andsbjerg (1993) indicated the presence of lowstand deposits associated with a sequence boundary in the Ravn-1 well. This part of the Jurassic succession, the Heno Formation, was deposited in the Kimmeridgian during a rift relaxation phase and a likely explanation for the formation of this boundary is a regional (eustatic?) sea-level fall. Sandstones may thus have been laid down in the basinal areas of the Tail End Graben and provide additional reservoir potential within the Jurassic succession. The turbidites encountered in the Jeppe-1 well were interpreted by Johannessen et al. (1996) to represent lowstand deposits. The sea-level lowstand is suggested to have promoted the deposition of coarse-grained deposits in the basinal areas, which only received argillaceous sediments during sea-level highstand (Plint 1988). The importance of sea-level changes is thought to be enhanced during the post-rift stage (Nøttvedt et al. 1995) or during intra-rift periods of tectonic quiescence, as is the case for the Heno Formation and the turbidites encountered in the Jeppe-1 well.

In the Middle Jurassic - lowermost Cretaceous succession of the Danish Central Graben, the three tectonic phases documented here are recorded by discrete sedimentary units showing characteristic architectural features. In the sequence stratigraphic study of this succession by Andsbjerg \& Dybkjær (2003, this volume), however, twelve sequences have been recognised, reflecting the interaction between the three major tectonic pulses described here and regional sea-level change.

\section{Conclusions}

The Danish Central Graben evolved through three distinct tectonic pulses. The first pulse, in Callovian to Early Oxfordian times, was concentrated along preexisting N-S-trending faults. The second pulse occurred during the Early Volgian, along new NNW-SSE-striking faults. Most of the fault blocks were tilted towards the east. During this pulse, salt tectonics became important for the location of sedimentary depocentres which were displaced away from the master fault resulting in a more symmetrical configuration of subbasins. The third pulse was a continuation of the second pulse but accompanied by local thrusting.

The structural framework controlled to some degree the distribution of reservoir sandstones. The most important potential reservoir facies related to periods with rotational tilt occur within the Middle Jurassic Bryne and Lulu Formations, and the Upper Jurassic 'Fife Sandstone Formation'. Reservoir sandstones related to tectonic relaxation are the Heno Formation and Upper Jurassic turbidites within the upper Farsund Formation. Regional (eustatic?) sea-level variation may have been important in the latter case, especially with respect to deposition of sands in basinal areas. 


\section{Acknowledgements}

The authors would like to thank Claus Andersen for preparing the geological maps and Nina Skårup for technical work on the geosections (Figs 3-5). Jan Andsbjerg, Karen Dybkjær and Ulrik Gregersen are thanked for valuable comments on the manuscript. Special thanks are due to John A. Korstgård, Arvid Nøttvedt and Jon R. Ineson for reviewing the manuscript.

\section{References}

Alexander, J. \& Leeder, M.R. 1987: Active tectonic control on alluvial architecture. In: Ethridge F.G., Flores, R.M. \& Harvey, M.D. (eds): Recent developments in fluvial sedimentology. Society of Economic Paleontologists and Mineralogists Special Publication 39, 243-252.

Andersen, C., Olsen, J.C., Michelsen, O. \& Nygaard, E. 1982: Structural outline and development. In: Michelsen, O. (ed.): Geology of the Danish Central Graben. Danmarks Geologiske Undersøgelse Serie B 8, 9-26.

Andsbjerg, J. 2003: Sedimentology and sequence stratigraphy of the Bryne and Lulu Formations, Middle Jurassic, northern Danish Central Graben. In: Ineson, J.R. \& Surlyk, F. (eds): The Jurassic of Denmark and Greenland. Geological Survey of Denmark and Greenland Bulletin 1, 301-347 (this volume).

Andsbjerg, J. \& Dybkjær, K. 2003: Sequence stratigraphy of the Jurassic of the Danish Central Graben. In: Ineson, J.R. \& Surlyk, F. (eds): The Jurassic of Denmark and Greenland. Geological Survey of Denmark and Greenland Bulletin 1, 265-300 (this volume).

Bergan, M., Tørudbakken, B. \& Wandås, B. 1989: Lithostratigraphic correlation of Upper Jurassic sandstones within the Norwegian Central Graben: sedimentological and tectonic implications. In: Collinson, J.D. (ed.): Correlation in hydrocarbon exploration, 243-251. London: Graham \& Trotman for the Norwegian Petroleum Society (NPF).

Britze, P., Japsen, P. \& Andersen, C. 1995: Geological map of Denmark. 1:200 000. The Danish Central Graben. 'Base Upper Jurassic' and the Upper Jurassic (two-way traveltime and depth, interval velocity and isochore). Danmarks Geologiske Undersøgelse Kortserie 50, 7 pp., 4 maps.

Cartwright, J.A. 1987: Transverse structural zones in continental rifts - an example from the Danish sector of the North Sea. In: Brooks, J. \& Glennie, K.W. (eds): Petroleum geology of North West Europe, 441-452. London: Graham \& Trotman.

Clausen, O.R., Korstgård, J.A. \& Egebjerg, T.M. 1996: Quantitative strain analysis of strike-slip displacement across the Arne-Elin trend, the Danish Central Graben. Bulletin of the Geological Society of Denmark 43, 99-113.

Collinson. J.D. 1988: Controls on Namurian sedimentation in the Central Province basins of northern England. In: Besly, B.M. \& Kelling, G. (eds): Sedimentation in a synorogenic basin complex; the Upper Carboniferous of Northwest Europe, 85-101. London: Blackie \& Son.
Damtoft, K., Nielsen, L.H., Johannessen, P.N., Thomsen, E. \& Andersen, P.R. 1992: Hydrocarbon plays of the Danish Central Trough. In: Spencer A.M. (ed.): Generation, accumulation and production of Europe's hydrocarbons II. European Association of Petroleum Geoscientists Special Publication 2, 35-58.

Gawthorpe, R.L., Fraser, A.J. \& Collier, R.E.L. 1994: Sequence stratigraphy in active extensional basins: implications for the interpretation of ancient basin-fills. Marine and Petroleum Geology 11, 642-658.

Gowers, M.B. \& Sæbøe, A. 1985: On the structural evolution of the Central Trough in the Norwegian and Danish sectors of the North Sea. Marine and Petroleum Geology 2, 298-318.

Gowers, M.B., Holtar, E. \& Swensson, E. 1993: The structure of the Norwegian Central Trough (Central Graben area). In: Parker J.R. (ed.): Petroleum geology of Northwest Europe: proceedings of the 4 th conference, 1245-1254. London: Geological Society.

Ineson, J.R., Bojesen-Koefoed, J.A., Dybkjær, K. \& Nielsen, L.H. 2003: Volgian-Ryazanian 'hot shales' of the Bo Member (Farsund Formation) in the Danish Central Graben, North Sea: stratigraphy, facies and geochemistry. In: Ineson, J.R. \& Surlyk, F. (eds): The Jurassic of Denmark and Greenland. Geological Survey of Denmark and Greenland Bulletin 1, 403-436 (this volume).

Jacobsen, F. 1982: Triassic. In: Michelsen, O. (ed.): Geology of the Danish Central Graben. Danmarks Geologiske Undersøgelse Serie B 8, 32-37.

Jacobsen, F.L. \& Larsen, J.G. 1982: Permian. In: Michelsen, O. (ed.): Geology of the Danish Central Graben. Danmarks Geologiske Undersøgelse Serie B 8, 28-32.

Japsen, P., Britze, P. \& Andersen, C. 2003: Upper Jurassic - Lower Cretaceous of the Danish Central Graben: structural framework and nomenclature. In: Ineson, J.R. \& Surlyk, F. (eds): The Jurassic of Denmark and Greenland. Geological Survey of Denmark and Greenland Bulletin 1, 233-246 (this volume).

Johannessen, P.N. 2003: Sedimentology and sequence stratigraphy of paralic and shallow marine Upper Jurassic sandstones in the northern Danish Central Graben. In: Ineson, J.R. \& Surlyk, F. (eds): The Jurassic of Denmark and Greenland. Geological Survey of Denmark and Greenland Bulletin 1, 367-402 (this volume).

Johannessen, P.N. \& Andsbjerg, J. 1993: Middle to Late Jurassic basin evolution and sandstone reservoir distribution in the Danish Central Trough. In: Parker, J.R. (ed.): Petroleum geology of Northwest Europe: proceedings of the 4th conference, 271-283. London: Geological Society.

Johannessen, P.N., Dybkjær, K. \& Rasmussen, E.S. 1996: Sequence stratigraphy of Upper Jurassic reservoir sandstones in the northern part of the Danish Central Trough, North Sea. Marine and Petroleum Geology 13, 755-770.

Koch, J.-O., Holm, L. \& Michelsen, O. 1982: Jurassic. In: Michelsen, O. (ed.): Geology of the Danish Central Graben. Danmarks Geologiske Undersøgelse Serie B 8, 37-45.

Kooi, H., Hettema, M. \& Cloetingh, S. 1991: Lithospheric dynamics and the rapid Pliocene-Quaternary subsidence phase in the southern North Sea basin. Tectonophysics 192, 245-259.

Korstgård. J.A., Lerche, I., Mogensen, T.E. \& Thomsen, R.O. 1993 
Salt and fault interactions in the northeastern Danish Central Graben: observations and inferences. Bulletin of the Geological Society of Denmark 40, 197-255.

Mackertich, D. 1996: The Fife Field, UK Central North Sea. Petroleum Geoscience 2, 373-380.

Michelsen, O. 1978: Stratigraphy and distribution of Jurassic deposits of the Norwegian-Danish Basin. Danmarks Geologiske Undersøgelse Serie B 2, 28 pp.

Michelsen, O. (ed.) 1982: Geology of the Danish Central Graben. Danmarks Geologiske Undersøgelse Serie B 8, 133 pp.

Michelsen, O., Nielsen, L.H., Johannessen, P.N., Andsbjerg, J. \& Surlyk, F. 2003: Jurassic lithostratigraphy and stratigraphic development onshore and offshore Denmark. In: Ineson, J.R. \& Surlyk, F. (eds): The Jurassic of Denmark and Greenland. Geological Survey of Denmark and Greenland Bulletin 1, 147-216 (this volume).

Møller, J.J. 1986: Seismic structural mapping of the Middle and Upper Jurassic in the Danish Central Trough. Danmarks Geologiske Undersøgelse Serie A 13, 37 pp.

Nielsen, L.H. \& Japsen, P. 1991: Deep wells in Denmark 1935-1990: Lithostratigraphic subdivision. Danmarks Geologiske Undersøgelse Serie A 31, 179 pp.

Nøttvedt, A., Gabrielsen, R.H. \& Steel, R.J. 1995: Tectonostratigraphy and sedimentary architecture of rift basins, with reference to the northern North Sea. Marine and Petroleum Geology 12, 881-901.

Plint, A.G. 1988: Sharp-based shoreface sequences and 'offshore' bars in the Cardium Formation of Alberta: their relationship to relative changes in sea level. In: Wilgus, C.K. et al. (eds): Sea-level changes - an integrated approach. Society of Economic Paleontologists and Mineralogists Special Publication 42, 357-370.

Prosser, S. 1993: Rift-related linked depositional systems and their seismic expression. In: Williams, G.D. \& Dobb, A. (eds): Tectonics and seismic stratigraphy. Geological Society Special Publication (London) 71, 35-66.

Rasmussen, E.S. 1995: The structural evolution of the Gert-Mjølner area. Marine and Petroleum Geology 12, 377-385.

Rasmussen, E.S., Lomholt, S., Andersen, C. \& Vejbæk, O.V. 1998: Aspects of the structural evolution of the Lusitanian Basin in Portugal and the shelf and slope area offshore Portugal. Tectonophysics 300, 199-226.

Rasmussen, E.S., Jepsen, A.-M. \& Maver, K.G. 1999: Upper Jurassic basin axial turbidites within the Gertrud Graben, Danish Central
Graben. In: Fleet, A.J. \& Boldy, S.A.R. (eds): Petroelum geology of Northwest Europe: proceedings of the 5th conference, 897-906. London: Geological Society.

Ravnaas, R. \& Steel, R.J. 1998: Architecture of marine rift-basin succession. American Association of Petroleum Geologists Bulletin 82, 110-146.

Ravnaas, R., Windelstad, J., Mellere, D., Nøttvedt, A., Stuhr Sjøblom, T., Steel, R.J. \& Wilson, R.C.L. 1997: A marine Late Jurassic synrift succession in the Lusitanian Basin, western Portugal - tectonic significance of stratigraphic signature. Sedimentary Geology 114, 237-266.

Søderstrøm, B., Forsberg, A., Holter, E. \& Rasmussen, B.A. 1991: The Mjølner Field, a deep Upper Jurassic oil field in the Central North Sea. First Break 9, 156-171.

Stemmerik, L., Ineson, J.R. \& Mitchell, J.G. 2000: Stratigraphy of the Rotliegend Group in the Danish part of the Northern Permian Basin, North Sea. Journal of the Geological Society (London) 157, 1127-1136.

Sundsbø, G.O. \& Megson, J.B. 1993: Structural styles in the Danish Central Graben. In: Parker, J.R. (ed.): Petroleum geology of Northwest Europe: proceedings of the 4th conference, 1255-1267. London: Geological Society.

Surlyk, F. 1989: Mid-Mesozoic synrift turbidite systems: controls and prediction. In: Collinson, J.D. (ed.): Correlation in hydrocarbon exploration, 231-241. London: Graham \& Trotman for the Norwegian Petroleum Society (NPF).

Underhill, J.R. \& Partington, M.A. 1993: Jurassic thermal doming and deflation in the North Sea: implications of the sequence stratigraphic evidence. In: Parker, J.R. (ed.): Petroleum geology of Northwest Europe: proceedings of the 4th conference, 337-346. London: Geological Society.

Vejbæk, O.V. 1986: Seismic stratigraphy and tectonic evolution of the Lower Cretaceous of the Danish Central Trough. Danmarks Geologiske Undersøgelse Serie A 11, 46 pp.

Vejbæk, O.V. 1992: Geodynamic modelling of the Danish Central Trough. In: Larsen, R.M. et al. (eds): Structural and tectonic modelling and its application to petroleum geology. Norwegian Petroleum Society (NPF) Special Publication 1, 1-17.

Ziegler, P.A. 1975: Geologic evolution of the North Sea and its tectonic framework. American Association of Petroleum Geologists Bulletin 59, 1073-1097.

Ziegler, P.A. 1982: Geological atlas of western and central Europe, 130 pp. The Hague: Elsevier for Shell Internationale Petroleum Maatschappij. 